\title{
Anfíbios do estado de Goiás e do Distrito Federal
}

\author{
Wilian Vaz-Silva \\ Natan Medeiros Maciel \\ Fausto Nomura \\ Alessandro Ribeiro de Morais \\ Vinícius Guerra Batista \\ Danusy Lopes Santos \\ Sheila Pereira Andrade \\ Arthur Ângelo Bispo de Oliveira \\ Reuber Albuquerque Brandão \\ Rogério Pereira Bastos
}

\section{SciELO Books / SciELO Livros / SciELO Libros}

VAZ-SILVA, W., MACIEL, N.M., NOMURA, F., MORAIS, A.R., BATISTA, V.G., SANTOS, D.L., ANDRADE, S.P., OLIVEIRA, A.Â.B., BRANDÃO, R.a., BASTOS, R.P. Anfíbios do estado de Goiás e do Distrito Federal. In: Guia de identificação das espécies de anfíbios (Anura e Gymnophiona) do estado de Goiás e do Distrito Federal, Brasil Central [online]. Curitiba: Sociedade Brasileira de Zoologia, 2020, pp. 14. Zoologia: guias e manuais de identificação series. ISBN: 978-65-87590-01-1. https://doi.org/10.7476/9786587590011.0003. \section{International license.}

All the contents of this work, except where otherwise noted, is licensed under a Creative Commons Attribution 4.0

Todo o conteúdo deste trabalho, exceto quando houver ressalva, é publicado sob a licença Creative Commons Atribição 4.0. 


\section{Anfíbios do estado de Goiás e do Distrito Federal}

São registradas 114 espécies de anfíbios (111 anuros e três cecílias) para Goiás e Distrito Federal, com maior riqueza observada nas regiões norte, nordeste e sudoeste (Figura 13). Este resultado pode ser justificado pela maior amostragem nestas regiões. As lacunas observadas no mapa indicam áreas ainda com deficiências de amostragem. A seguir é apresentado o checklist das espécies de anfíbios de Goiás e Distrito Federal.

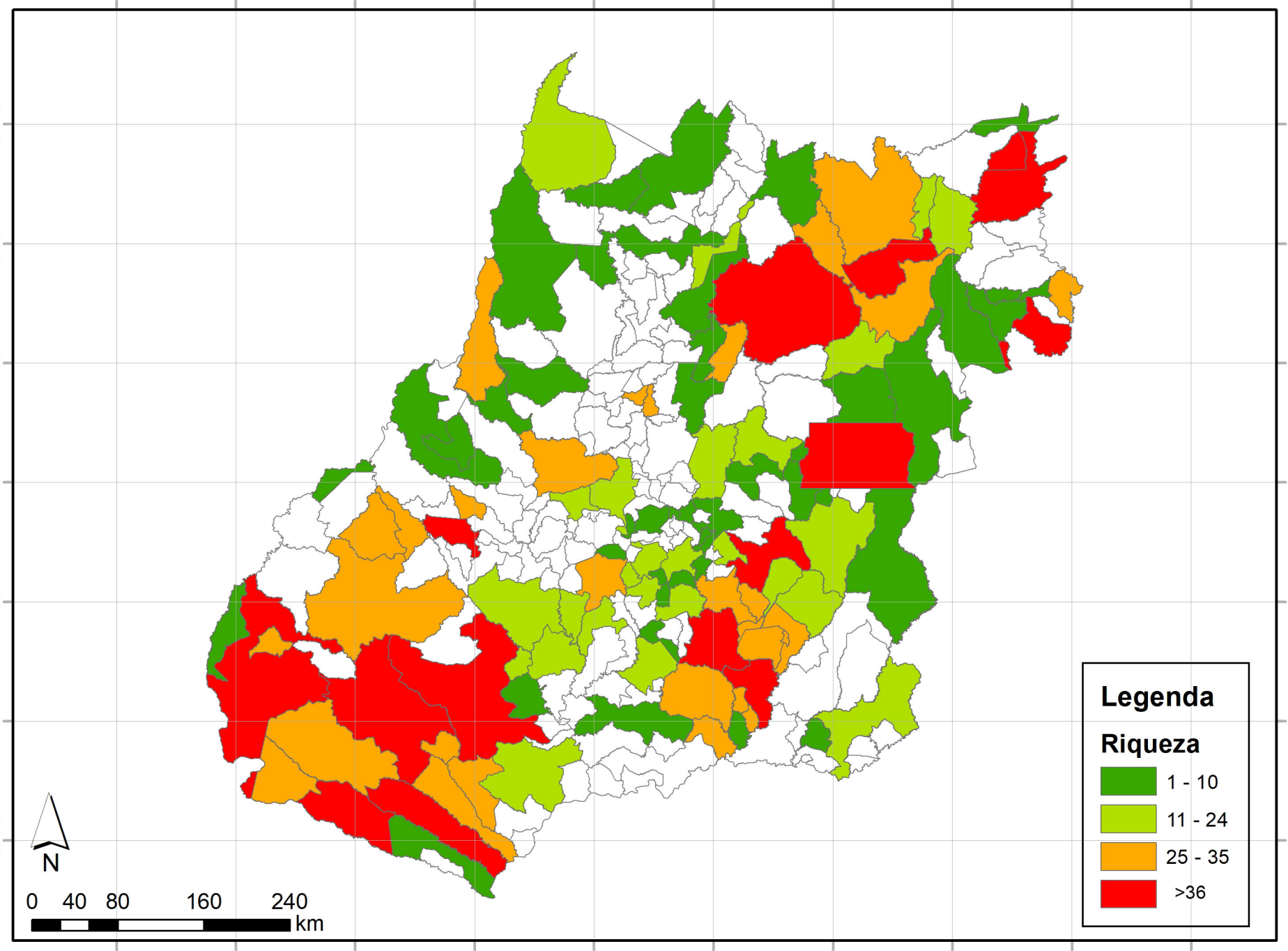

Figura 13. Distribuição dos dados levantados evidenciando áreas melhores amostradas para os anfíbios do estado de Goiás e Distrito Federal. 